\title{
Effect of Patah Tulang Latex (Euphorbia tirucalli L.) on Wound Healing in
} Wistar Rat

\author{
Galuh Ratnawati ${ }^{*}$, Kurniasih Kurniasih ${ }^{2}$, Surya Amanu ${ }^{3}$
}

${ }^{1}$ Balai Besar Penelitian dan Pengembangan Tanaman Obat dan Obat Tradisional, Tawangmangu

${ }^{2}$ Departement of Pathology, FKH-UGM, Yogyakarta

${ }^{3}$ Departement of Microbiology, FKH-UGM,Yogyakarta

Submitted 17 December 2017; Revised 24 May 2019; Accepted 18 July 2019; Published 18 October 2019

*Corresponding author: galuhratnagaluh@gmail.com

\begin{abstract}
Wound healing process occured on four phases such as hemostatis, inflammation, and maturation. Latex of Patah Tulang (Euphorbia tirucalli L.) can heal the wound because of its active compound. Aim of this research was to find out the effect of ointment topical of E. tirucalli L. to wound healing process based on macroscopic and microscopic examination and cellular reaction on $\mathrm{CD} 4^{+}$lymphocyte. Male Wistar Rat, 2 month old, 150-200 Gram of body weight, as much as 36 rats. Rats were divided into 4 groups, and were anesthesized before being punctioned on the 2 sides of lateral vertebrae. Group one was used as a control, group two was given treatment with the ointment $9 \%$ of E. tirucalli L., group three was given with $23 \%$ of E. tirucalli L., and group four was given madecassol ${ }^{\circledR}$. Treatment was given once a day for 15 days. Macroscopical and microscopical changes were observed at the fifth, tenth, and fifteenth day. Macroscopical observation was the diameter of wound. Microscopical observation consisted of epidermal thicness, number of fibroblast, using Haematoxylin and Eosin staining, and cellular reaction of $\mathrm{CD}^{+}$lymphocyte using imunohistochemistry. The results showed that topical administration of E. tirucalli ointment $9 \%$ and $23 \%$ potential to accelerate wistar skin wound healing puncture wounds. There was no difference between E. tirucalli ointment $9 \%$ and $23 \%$ application to observed parameters.
\end{abstract}

Keywords: Euphorbia tirucalli L., injure healing, macroscopic, microscopic, lymphocyte CD4 ${ }^{+}$

\section{Pengaruh Getah Patah Tulang (Euphorbia tirucalli L.) Terhadap Kesembuhan Luka Pada Tikus Putih}

\section{Abstrak}

Kesembuhan luka terjadi melalui empat fase, yaitu hemostasis, inflamasi, proliferasi dan maturasi. Tumbuhan patah tulang (Euphorbia tirucalli L.) memiliki potensi untuk membantu proses kesembuhan luka karena kandungan beberapa senyawa aktifnya. Penelitian ini bertujuan untuk mengetahui efek aplikasi topikal salep E.tirucalli L. terhadap kesembuhan luka pungsi pada tikus putih secara makroskopik dan mikroskopik serta reaksi seluler limfosit $\mathrm{CD} 4^{+}$. Tikus Wistar jantan umur 2 bulan dan berat badan antara 150-200 gram sebanyak 36 ekor dibagi kelompok masing-masing 9 ekor tikus. Tikus dianestesi, dicukur rambut dan dipungsi pada kedua sisi lateral vertebrae. Kelompok 1 digunakan sebagai kontrol, kelompok 2 diaplikasi topikal salep E. tirucalli L. 9\%, kelompok 3 diberi salep E. tirucalli L. 23\% dan kelompok 4 diberi salep madecassol ${ }^{\circledR}$. Terapi diberikan sehari sekali selama 15 hari. Pengamatan secara makroskopik dan mikroskopik pada hari ke-5, 10 dan 15. Pengamatan makroskopik diameter luka. Pengamatan mikroskopik ketebalan epidermis, jumlah fibroblas dengan pewarnaan Hematoxilin dan Eosin (HE) serta reaksi seluler limfosit $\mathrm{CD}^{+}$dengan pewarnaan imunohistokimia (IHK). Hasil pengamatan menunjukkan pemberian salep E. tirucalli $9 \%$ dan 23\% mempercepat kesembuhan luka pungsi dengan parameter makroskopik persentase area luka, mikroskopik ketebalan epidermis dan jumlah limfosit $\mathrm{CD}^{+}$. Jumlah fibroblas tidak berbeda nyata terhadap kelompok kontrol. Tidak ada perbedaan antara pemberian salep E. tirucalli $9 \%$ dan 23\% terhadap parameter yang diamati.

Kata Kunci: Euphorbia tirucalli L., kesembuhan luka, makroskopik, mikroskopik, limfosit CD4 ${ }^{+}$ 


\section{Pendahuluan}

Getah Euphorbia tirucalli L. mengandung senyawa aktif berupa alkaloid, flavonoid, fenol, tanin, steroid, terpenoid, glikosida,inganen, euphol, sterol, $\alpha$-euphorbol, taraxasterol, tirucallol. ${ }^{1}$ Flavonoid dan tanin, bermanfaat untuk penanganan luka terbuka. ${ }^{2}$ Aktivitas antioksidan, antiinflamasi, dan analgesik getah E. tirucalli L. dapat membantu dalam proses kesembuhan luka.

Proses kesembuhan luka melibatkan serangkaian fase yaitu hemostasis, inflamasi, proliferasi, serta maturasi dan remodelling. Kesembuhan luka terdapat 4 fase, yaitu: (1) hemostasis, (2) inflamasi, (3) proliferasi dan (4) maturasi dan remodelling. ${ }^{3,4}$ Hemostasis merupakan respon cepat dari kelukaan kulit dan platelet berperan penting dalam pembentukan clot. Fase Inflamasi melibatkan berbagai sitokin, kemokin dan sel radang. Sel radang yang terlibat antara lain makrofag, neutrofil dan limfosit. Limfosit $\mathrm{T}$ dalam fase ini mengekspresi $\mathrm{CD}^{+} \quad$ (T-helper) dan mengaktivasi faktor kesembuhan luka yang lain. Fase selanjutnya proliferasi ditandai dengan epitelialisasi, fibroplasia, dan angiogenesis. Remodelling adalah fase terakhir ditandai dengan terbentuknya kolagen yang terkoordinasi. ${ }^{3}$

Setelah clot terbentuk selanjutnya diikuti oleh faktor kesembuhan meliputi platelet derived growth factor (PDGF), transforming growth factor- $\beta$ (TGF- $\beta$ ). Platelet akan meningkatkan vaskularisasi suplai darah menuju ke jaringan luka dengan adanya serotonin. Serotonin meningkatkan ekstravasasi cairan ke dalam jaringan luka yang menimbulkan edema yang merupakan tahap awal fase inflamasi. ${ }^{4,5}$

Infiltrasi neutrofil di jaringan luka akan mengalami penurunan ketika agen infeksi telah terfagosit, selanjutnya sel nekrosis dihancurkan oleh makrofag. ${ }^{5}$ Makrofag akan memasuki jaringan bersama dengan komponen inflamasi yang lain seperti sitokin, PDGF, TGF- $\beta$, leukotrin serta prostaglandin. Pada tahap ini timbul nyeri pada luka yang berlebihan akibat adanya prostaglandin pada jaringan luka.

Komponen imunologi lain yang berperan penting dalam proses kesembuhan luka adalah sel T. Permukaan sel T tersusun atas berbagai reseptor yang menjalankan fungsi dan perannya masing-masing. Permukaan sel $\mathrm{T}$ memberikan sinyal yang menginduksi ekspresi $\mathrm{CD}^{+}$mengaktivasi faktor kesembuhan luka yang lain seperti IFN $\gamma$, IL-2, IL-3, TEGF, COX dan lain sebagainya. ${ }^{6}$ Tujuan penelitian ini adalah untuk mengetahui potensi aplikasi topikal getah E. tirucalli L. terhadap proses kesembuhan luka pungsi pada kulit tikus uji secara makroskopik dan mikroskopik serta reaksi seluler limfosit $\mathrm{CD}^{+}$.

\section{Metode}

2.1. Pembuatan salep E. tirucalli L.

Batang dan cabang tumbuhan E. tirucalli

L. dibersihkan terlebih dahulu dengan alkohol $70 \%$ dan ditunggu kering, selanjutnya disayat sampai mengeluarkan getah dan ditampung dalam gelas ukur. ${ }^{7}$ Salep E. tirucalli L. yang digunakan adalah $9 \%$ dan $23 \%$ dibuat dengan komposisi pada Tabel 1

Bahan ditimbang sesuai komposisi, vaselin dipanaskan dalam cawan poselin diatas hotplate $100^{\circ} \mathrm{C}$ sampai meleleh. Cera alba diambil dari dalam vaselin, tunggu sampai leleh,dimasukkan diaduk rata hingga suhu $80^{\circ} \mathrm{C}$, ditambahkan $\mathrm{KOH}$, diaduk hingga larut. Mortar yang sudah dipanaskan, dimasukkan basis salep dan ditambahkan getah, diaduk cepat dengan stamper sampai merata. ${ }^{8}$ Penentuan konsentrasi salep

Tabel 1. Komposisi salep E. tirucalli $\mathrm{L}^{8}$

\begin{tabular}{lcc}
\hline \multicolumn{1}{c}{ Komposisi } & Konsentrasi $9 \%$ (gram) & Konsentrasi 23\% (gram) \\
\hline Vaselin putih & 8 & 8 \\
Kalium hidroksida $(\mathrm{KOH})$ & 0,05 & 0,05 \\
Gliserin & 0,95 & 0,95 \\
Cera alba & 1 & 1 \\
Getah E. tirucalli L. & 1 & 3 \\
\hline
\end{tabular}


didasarkan pada penelitian Qomariah dan Aisah. ${ }^{9,10}$

\subsection{Persiapan dan pengelompokan hewan} uji

Tikus putih galur Wistar jantan 2 bulan 150-200 Gram sebanyak 36 ekor dibagi 4 kelompok, masing-masing 9 ekor. Semua tikus diadaptasi selama 1 minggu sebelum perlakuan.

Tikus dianastesi menggunakan kombinasi ketamine dan xylasin dengan dosis 75 dan $5 \mathrm{mg} / \mathrm{kg}$ BB secara intramuskuler. ${ }^{11}$ Tikus dicukur rambut daerah punggung, diolesi dengan bethadine, dibuat luka pungsi 2 buah pada kedua sisi lateral vertebrae dengan diameter $4 \mathrm{~mm}$ dan kedalaman hingga sub kutan menggunakan biopsy puncher dan gunting. Luka pungsi pada tikus kelompok 1 diberi salep tanpa getah E. tirucalli, kelompok 2 diberi topikal salep getah E. tirucalli 9\%., kelompok 3 diberi topikal salep getah $E$. tirucalli 23\%, dan kelompok 4 diberi topikal madecassol ${ }^{\circledR}$ sekali sehari. Pengamatan proses kesembuhan luka dilakukan pada hari ke-5, 10, dan 15 setelah dilakukan pungsi.

\subsection{Pengukuran parameter kesembuhan luka}

Tikus dieutanasi menggunakan eter, dan jaringan luka difiksasi dengan phosphate buffered formalin 9\% selama 24 jam, selanjutnya diproses histopatologis dengan pewarnaan Hematoxilin dan Eosin (HE), dan imunohistokimia dengan antibodi anti $\mathrm{CD}^{+}$. Penelitian telah mendapatkan persetujuan dari Komisi Ethical Clearance LPPT, Universitas Gadjah Mada, Yogyakarta dengan nomor 00135/04/LPPT/XI/2017, tanggal 8 November 2017.

Parameter kesembuhan luka dilakukan secara makroskopik dan mikroskopik pada luka kulit tikus. Pengamatan makroskopik luka dengan mengukur persentase area luka berdasarkan luas area luka. Menurut Bush et al. ${ }^{12}$ luas area luka dan persentase area luka dihitung dengan rumus berikut:

\section{Luas (luka berbentuk bulat) $=\pi \times \mathrm{d} 1 \times \mathrm{d} 2$}

Keterangan: d1 (diameter luka 1); d2 (diameter luka 2).

Luas area luka yang diperoleh selanjutnya dihitung persentasenya dengan rumus sebagai berikut:

$$
\begin{aligned}
& \text { Persentase area luka (\%) } \\
& =\left[\frac{\text { Luas area luka hari }(x)}{\text { Luas area luka hari }(0)}\right] \times 100
\end{aligned}
$$

Pengamatan mikroskopik dengan pewarnaan HE dilakukan terhadap ketebalan epidermis dan jumlah fibroblas. Pengamatan mikroskopik secara imunohistokimia dengan antibodi anti $\mathrm{CD} 4^{+}$dilakukan menggunakan penghitungan jumlah limfosit yang mengekpresikan $\mathrm{CD}^{+}$.

\subsection{Analisis data}

Data kesembuhan luka berupa makroskopik dan mikroskopik terdiri atas ketebalan epidermis, jumlah fibroblas, dan jumlah limfosit $\mathrm{CD}^{+}$dianalisa secara statistik menggunakan software SPSS 16.

\section{Hasil}

3.1. Persentase area luka

Persentase area luka kulit tikus pada pengamatan hari ke- 5, 10 dan 15 disajikan pada Tabel 2 dan Gambar 1.

\subsection{Ketebalan epidermis luka kulit \\ Pengamatan dan pengukuran ketebalan} epidermis menggunakan mikroskop dan mikrometer pada preparat histopatologi kulit

Tabel 2. Rata - rata \pm SD persentase area luka kulit tikus hari ke- 5, 10 dan 15

\begin{tabular}{lccc}
\hline \multicolumn{1}{c}{ Kelompok } & \multicolumn{3}{c}{ Persentase Area Luka (Rerata \pm SD hari ke-) } \\
& 5 & 10 & 15 \\
\hline Kontrol & $61,68 \pm 4,55^{\mathrm{a}, \mathrm{a}}$ & $36,10 \pm 17,66^{\mathrm{a}, \mathrm{b}}$ & $9,05 \pm 1,13^{\mathrm{a}, \mathrm{c}}$ \\
Salep E. tirucalli 9\% & $43,31 \pm 14,09^{\mathrm{b}, \mathrm{a}}$ & $3,66 \pm 3,46^{\mathrm{b}, \mathrm{b}}$ & $0,00 \pm 0,00^{\mathrm{b}, \mathrm{c}}$ \\
Salep E. tirucalli 23\% & $29,60 \pm 7,62^{\mathrm{b}, \mathrm{a}}$ & $0,44 \pm 0,38^{\mathrm{b}, \mathrm{b}}$ & $0,00 \pm 0,00^{\mathrm{b}, \mathrm{c}}$ \\
Madecassol & $43,98 \pm 14,15^{\mathrm{b}, \mathrm{a}}$ & $10,09 \pm 17,51^{\mathrm{b}, \mathrm{b}}$ & $2,26 \pm 4,12^{\mathrm{b}, \mathrm{c}}$ \\
\hline
\end{tabular}


yang diwarnai dengan hematoksilin eosin. Hasil pengukuran disajikan dalam Tabel 3.

\subsection{Jumlah fibroblas}

Jumlah fibroblas dihitung dengan menghitung rata-rata jumlah fibroblst pada 5 lapang pandang pada pengamatan preparat histopatologi. Hasil pengitungan ditampilkan dalam Tabel 4.

\subsection{Jumlah limfosit CD $4^{+}$}

Jumlah limfosit $\mathrm{CD}^{+}$dihitung dengan menghitung rata-rata jumlah fibroblast pada 5 lapang pandang pada pengamatan preparat histopatologi. Hasil pengitungan ditampilkan dalam Tabel 5.

\section{Pembahasan}

Penyembuhan luka adalah proses yang vital untuk kelangsungan hidup semua organisme tingkat tinggi. Pemahaman yang lebih baik dari mekanisme seluler dan molekuler yang mendasarinya penyembuhan luka memungkinkan untuk mengembangkan metode mempercepat perbaikan luka/ proses regenerasi. ${ }^{13}$

\subsection{Persentase area luka}

Pengukuran persentase area luka dengan mengukur diameter luka pada luka berbentuk bulat seperti yang dilakukan pada penelitian ini. ${ }^{12}$ Persentase area luka kulit tikus mengalami penurunan mulai hari ke 5 hingga ke 15, dan berbeda antara satu kelompok dengan kelompok lainnya.Hal tersebut dibuktikan pada hasil uji Kruskal-Wallis $\operatorname{sig}=0,024(\operatorname{sig} \leq 0,05)$, yang menunjukkan bahwa terdapat perbedaan terhadap semua kelompok perlakuan. Kelompok kontrol memperlihatkan penurunan persentase area luka terjadi lebih lambat dibanding kelompok yang lain. Kelompok salep E. tirucalli
9\%, 23\% dan madecassol memperlihatkan penurunan persentase area luka yang lebih cepat pada hari ke 5 dan 10 (Gambar 1).

Pengamatan area luka secara rutin dapat menjadi sumber informasi perkembangan kesembuhan luka sehingga dapat menjadi panduan untuk menentukan intervensi lanjut pengobatan dan mencegah penanganan yang tidak efektif. Persentase area luka kulit tikus mengalami penurunan mulai hari ke 5 hingga ke 15, dan berbeda antara satu kelompok dengan kelompok lainnya. Hal tersebut dibuktikan pada hasil uji Kruskal-Wallis sig = $0,024$ ( $\operatorname{sig} \leq 0,05)$, yang menunjukkan bahwa terdapat perbedaan terhadap semua kelompok perlakuan.

Perbaikan dan kesembuhan luka umumnya membutuhkan 2 proses utama yaitu pembentukan clot yang cepat dan pembentukan keropeng untuk melindungi luka dan regenerasi jaringan lebih lanjut. Keropeng menghentikan perdarahan dan secara fisik melindungi luka dari infeksi. ${ }^{14}$ Pemberian secara topikal salep E. tirucalli $9 \%$, 23\% menghasilkan pembentukan keropeng yang lebih cepat dibandingkan dengan kelompok kontrol (Gambar 1). Keropeng sudah terbentuk pada hari ke-5 sedangkan pada kelompok kontrol terlihat luka masih terbuka. Pada hari ke-10 keropeng baru terlihat pada kelompok kontrol, sedangkan kelompok salep E. tirucalli 9\%, 23\% dan madecassol terlihat keropeng telah terlepas dan luka telah menutup sempurna, walaupun pada kelompok salep E. tirucalli 9\% masih terlihat bekas lepasan keropeng.

Keropeng sudah terbentuk pada hari ke-5 sedangkan pada kelompok kontrol terlihat luka masih terbuka. Pada hari ke-10 keropeng baru terlihat pada kelompok kontrol, sedangkan kelompok salep E. tirucalli 9\%, $23 \%$ dan madecassol terlihat keropeng telah

Tabel 3. Rata - rata \pm standar deviasi (SD) ketebalan epidermis luka kulit tikus hari ke- 5, 10 dan 15

\begin{tabular}{lccc}
\hline \multicolumn{1}{c}{ Kelompok } & \multicolumn{3}{c}{ Ketebalan Epidermis (Rerata \pm SD hari ke-) } \\
& 5 & 10 & 15 \\
\hline Kontrol & $19,13 \pm 6,86^{\mathrm{a}, \mathrm{a}}$ & $24,72 \pm 3,33^{\mathrm{a}, \mathrm{b}}$ & $34,29 \pm 5,97^{\mathrm{a}, \mathrm{c}}$ \\
Salep E. tirucalli 9\% & $47,85 \pm 10,45^{\mathrm{b}, \mathrm{a}}$ & $43,34 \pm 10,52^{\mathrm{b}, \mathrm{b}}$ & $45,43 \pm 5,48^{\mathrm{b}, \mathrm{c}}$ \\
Salep E. tirucalli 23\% & $46,40 \pm 10,45^{\mathrm{b}, \mathrm{a}}$ & $47,36 \pm 7,29^{\mathrm{b}, \mathrm{b}}$ & $57,51 \pm 3,64^{\mathrm{b}, \mathrm{c}}$ \\
Madecassol & $31,24 \pm 4,57^{\mathrm{c}, \mathrm{a}}$ & $38,08 \pm 5,76^{\mathrm{c}, \mathrm{b}}$ & $41,81 \pm 10,71^{\mathrm{c}, \mathrm{c}}$ \\
\hline
\end{tabular}




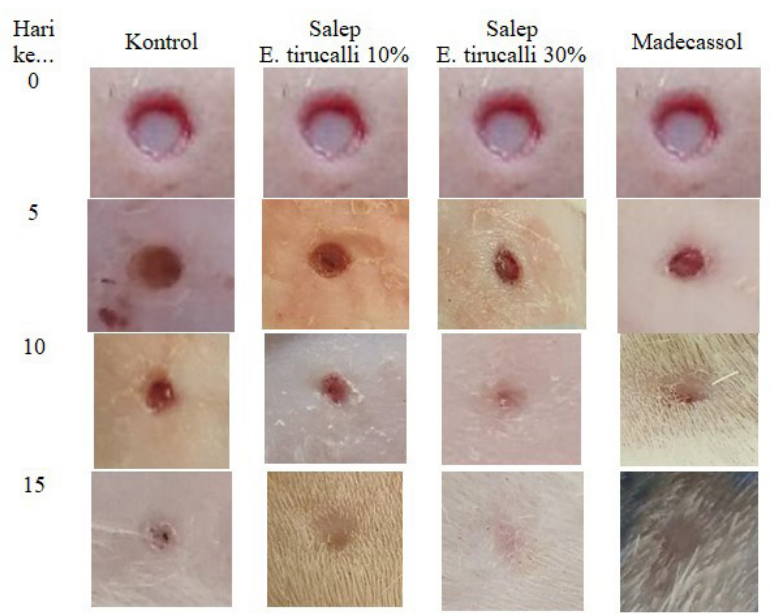

Gambar 1. Area luka kulit tikus hari ke 0, 5, 10 dan 15.

terlepas dan luka telah menutup sempurna, walaupun pada kelompok salep E. tirucalli 9\% masih terlihat bekas lepasan keropeng.

Salep ekstrak batang E. tirucalli 9\% mempercepat kesembuhan luka sayat dengan adanya pembentukan jaringan baru pada hari ke-9, sedangkan pada konsentrasi $20 \%$ pembentukan jaringan baru justru terlihat pada hari ke-139. Hal ini berbeda dengan hasil yang didapatkan pada penelitian ini, bahwa pada hari ke-10 pemberian salep getah E. tirucalli $9 \%$, maupun $23 \%$ telah menunjukkan penutupan luka, meskipun penutupan luka pada kelompok tikus yang diberikan salep getah E. tirucalli 23\% justru terlihat lebih baik. Kesembuhan luka yang lebih baik pada kelompok dengan salep E. tirucalli diduga karena kandungan flavonoid dan euphol yang bersifat antiinflamasi. ${ }^{15,16}$

\subsection{Ketebalan epidermis luka kulit}

Ketebalan epidermis luka kulit tikus berdasarkan uji two-way ANOVA pada penelitian ini menunjukkan adanya perbedaan nyata dengan nilai sig $=0,000(\operatorname{sig} \leq 0,05)$. Dengan uji post hoc Tukey HSD ketebalan epidermis luka kulit tikus kelompok salep
E. tirucalli 9\%, 23\% dan madecassol berbeda nyata jika dibandingkan dengan kelompok kontrol (sig $\leq 0,05)$, kelompok salep E. tirucalli $23 \%$ berbeda nyata jika dibandingkan dengan kelompok madecassol, sedangkan perbedaan tidak nyata nampak pada kelompok salep E. tirucalli $9 \%$ dibandingkan dengan kelompok salep E. tirucalli 23\% dan kelompok madecassol (Tabel 3).

Pengamatan mikroskopis preparat histopatologi menunjukkan terbentuknya klot pada epidermis pada hari ke 5 (kelompok kontrol). Epidermis terbentuk di hari ke 15, namun masih terlihat adanya clot di permukaan area luka dan hemoragi di dermis. Kelompok terapi salep E. tirucalli 9\% dan $23 \%$ pada hari ke 15 banyak pembentukan epidermis yang baik dan dibuktikan dengan mulai terbentuknya keratin, namun masih dijumpai adanya perdarahan di dermis. Kelompok madecassol ${ }^{\circledR}$ pada hari ke 15 memperlihatkan hasil paling baik terhadap pembentukan epidermis dan keratin, serta tidak ditemukan adanya perdarahan.

Reepitelialisasi memerlukan migrasi dan proliferasi dari keratinosit. Keratinosit pada lamina basalis dari daerah luka mulai

Tabel 4. . Rata - rata \pm standar deviasi (SD) jumlah fibroblas pada luka kulit tikus hari ke- 5, 10 dan 15

\begin{tabular}{lccc}
\hline \multicolumn{1}{c}{ Kelompok } & \multicolumn{3}{c}{ Jumlah Fibroblas (Rerata \pm SD hari ke-) } \\
& 5 & 10 & 15 \\
\hline Kontrol & $314,00 \pm 2,64^{\mathrm{a}, \mathrm{a}}$ & $73,67 \pm 19,42^{\mathrm{b}, \mathrm{a}}$ & $88,67 \pm 59,91^{\mathrm{a}, \mathrm{c}}$ \\
Salep E. tirucalli 9\% & $11,67 \pm 2,89^{\mathrm{a}, \mathrm{a}}$ & $117,67 \pm 18,93^{\mathrm{b}, \mathrm{a}}$ & $210,67 \pm 13,05^{\mathrm{a}, \mathrm{c}}$ \\
Salep E. tirucalli 23\% & $11,00 \pm 2,00^{\mathrm{a}, \mathrm{a}}$ & $96,00 \pm 13,11^{\mathrm{b}, \mathrm{a}}$ & $175,00 \pm 30,64^{\mathrm{a}, \mathrm{c}}$ \\
Madecassol & $13,00 \pm 7,00^{\mathrm{a}, \mathrm{a}}$ & $110,33 \pm 17,62^{\mathrm{b}, \mathrm{a}}$ & $188,33 \pm 71,84^{\mathrm{a}, \mathrm{c}}$ \\
\hline
\end{tabular}


Tabel 5. Rata - rata \pm standar deviasi jumlah limfosit $C D 4^{+}$pada luka kulit tikus hari ke- 5, 10 dan 15

\begin{tabular}{lccc}
\hline \multicolumn{1}{c}{ Kelompok } & \multicolumn{3}{c}{ Jumlah Limfosit CD4 $($ Rerata \pm SD hari ke- $)$} \\
\hline Kontrol & 5 & 10 & 15 \\
Salep E. tirucalli 9\% & $35,00 \pm 12,00^{\mathrm{a}, \mathrm{a}}$ & $32,33 \pm 30,92^{\mathrm{a}, \mathrm{a}}$ & $21,33 \pm 7,50^{\mathrm{a}, \mathrm{a}}$ \\
Salep E. tirucalli 23\% & $17,67 \pm 3,78^{\mathrm{a}, \mathrm{b}}$ & $1,67 \pm 1,15^{\mathrm{b}, \mathrm{a}}$ & $3,33 \pm 2,51^{\mathrm{a}, \mathrm{b}}$ \\
Madecassol & $13,67 \pm 4,72^{\mathrm{a}, \mathrm{b}}$ & $3,00 \pm 1,73^{\mathrm{b}, \mathrm{a}}$ & $2,33 \pm 0,58^{\mathrm{b}, \mathrm{b}}$ \\
\hline
\end{tabular}

berproliferasi 2-3 hari setelah terjadinya luka. Migrasi dipicu oleh hilangnya kontak hambatan dan tekanan fisik pada struktur perlekatan sel dan akan berhenti ketika sel telah terbentuk perlekatan yang baru. Reepitelialisasi distimulasi oleh makrofag, sitokin, growth factors yang disekresikan oleh beragam sel pada luka. ${ }^{17}$

Segera setelah terjadi luka, tubuh akan merespon dengan terbentuknya clot untuk mencegah perdarahan. Clot terdiri dari kolagen, platelet, trombin, dan fibronektin. ${ }^{4}$ Terbentuknya kembali epidermis dimulai dengan adanya sel yang bermigrasi dan berproliferasi. Stimulus proliferasi dan kemotaksis adalah EGF dan TGF- $\alpha$ yang diproduksi oleh platelet aktif dan makrofag. Epitelialisasi merupakan komponen penting dari penyembuhan luka dan digunakan sebagai parameter penentu keberhasilan penutupan luka. Luka tidak bisa dianggap sembuh tanpa adanya epitelisasi ulang. Proses seluler dan molekuler yang terlibat dalam inisiasi, pemeliharaan, dan penyelesaian epitelisasi sangat penting untuk keberhasilan penutupan luka. ${ }^{18}$

\subsection{Jumlah fibroblast}

Jumlah fibroblast pada luka kulit tikus dalam penelitian ini memperlihatkan tidak adanya perbedaan nyata pada kelompok perlakuan. Hal tersebut ditunjukkan oleh hasil uji Kruskal-Wallis dengan nilai $p=0,212(p \geq$ $0,05)$. Perbedaan nyata terdapat pada hasil uji antar waktu pengambilan data dimana jumlah fibroblas semakin meningkat, Tabel 4. Jumlah fibroblas yang teramati pada hari ke-5, 10, dan 15 signifikan berbeda, dengan kecenderungan semakin meningkat. Peningkatan jumlah fibroblas terjadi pada kelompok kontrol seperti pada kelompok salep E. tirucalli $9 \%$, $23 \%$ dan madecassol.
Fibroblast sangat penting dalam mendukung penyembuhan luka normal, yang terlibat dalam proses-proses penting seperti memecah gumpalan fibrin, menciptakan matriks seluler ekstra baru (ECM) dan struktur kolagen untuk mendukung sel-sel lain yang terkait dengan penyembuhan luka yang efektif, serta mengontraksi luka. ${ }^{19,20}$ Pada jaringan yang terluka, fibroblas diaktifkan dan berdiferensiasi menjadi myofibroblast, yang berkontraksi dan berpartisipasi dalam penyembuhan dengan mengurangi ukuran luka dan mensekresi protein ECM. Myofibroblast pada luka kulit umumnya dipercayai berasal dari rekrutmen lokal fibroblast di dermis dan jaringan subkutan yang mengelilingi luka, perisit serta sel otot polos..$^{21}$ Pemberian salep E. tirucalli $9 \%$ dan $23 \%$ menunjukkan tren yang sesuai dimana pada hari ke-10 fibroblas meningkat sampai teramati pada hari ke-15.

\subsection{Jumlah limfosit CD4 ${ }^{+}$}

Jumlah limfosit $\mathrm{CD}^{+}$pada luka kulit tikus menunjukkan adanya perbedaan nyata yang dibuktikan oleh hasil uji Kruskal-Wallis dengan nilai $p=0,000(p \leq 0,05)$. Hasil uji Mann-Whitney U memperlihatkan bahwa adanya perbedaan nyata jumlah limfosit $\mathrm{CD}^{+}$kelompok kontrol dengan kelompok salep E. tirucalli 9\%, kelompok salep $E$. tirucalli $23 \%(\mathrm{p} \leq 0,05)$. Penelitian ini menunjukkan bahwa jumlah limfosit CD4 ${ }^{+}$ di jaringan luka pada kelompok salep $E$. tirucalli $9 \%$ dan 23\%, kelompok kontrol dan madecassol cenderung semakin menurun. Hasil menunjukkan nampak adanya limfosit $\mathrm{CD}^{+}$yang menginfiltrasi jaringan luka pada hari ke-5. Jumlah limfosit $\mathrm{CD}^{+}$menurun pada hari ke-10 baik pada kelompok kontrol, salep E. tirucalli 9\%, 23\% maupun kelompok madecassol.

Ketika kulit mengalami kelukaan, 
antigen yang tidak dikenali mengekspresikan pada keratinosit yang rusak sehingga TCR $\gamma \delta$ memproduksi epithelial growth factors dan sitokin inflamatori. ${ }^{22} \mathrm{TCR} \gamma \delta$ mengekspresikan $\mathrm{CD}^{+}$yang berperan sebagai transduser sinyal, dan $\mathrm{CD}^{+}$serta $\mathrm{CD}^{+}$sebagai ko-reseptor. Limfosit $\mathrm{CD}^{+}$dan $\mathrm{CD}^{+}$menginfiltrasi luka kulit secara progresif, hanya setelah neutrofil dan makrofag dan setelah luka mengalami re-epitelialisasi. Tidak adanya limfosit $\mathrm{CD}^{+}$dan $\mathrm{CD}^{+}$meningkatkan kekuatan pemecahan luka dan tingkat kolagen. ${ }^{23}$ Pemberian salep E. tirucalli 9\% dan 23\% menyebabkan munculnya limfosit $\mathrm{CD}^{+}$ lebih tinggi dibandingkan kelompok kontrol meskipun tidak signifikan secara statistik dan tetap tinngi sampai hari ke-15 berkebalikan dengan kelompok madecassol yang semakin menurun. Hal ini selaras dengan penelitian Avelar et. al. ${ }^{24}$ bahwa inkubasi in vitro selama 4 jam leukosit darah perifer dengan getah $E$. tirucalli yang didilusi pada dimetilsufoksida meningkatkan persentase limfosit $\mathrm{T}$ positif $\mathrm{CD}^{+}{ }^{+}$secara signifikan.

\section{Simpulan}

Pemberian topikal salep E. tirucalli $9 \%$ dan $23 \%$ berpotensi terhadap percepatan kesembuhan luka pungsi kulit tikus Wistar secara makroskopik berdasarkan persentase area luka, dan mikroskopik berdasarkan ketebalan epidermis dan jumlah limfosit $\mathrm{CD}^{+}$. Jumlah fibroblas tidak berbeda nyata terhadap kelompok kontrol. Tidak ada perbedaan antara pemberian salep E. tirucalli $9 \%$ dan $23 \%$ terhadap parameter yang diamati.

\section{Daftar Pustaka}

1. Manoorkar V dan Gachande BD. Phytochemical analysis of some plant latex. Int. J. Of Life Science. 2015;3(1):108-110.

2. Upadhyay B, Singh K, Kumar A. Ethno-medical, Phytochemical and Antimicrobial Sudies of Euphorbia tirucalli L. Journal of Phytology. 2010;2 (4):65-77.

3. Sundaramurthi D, Krishnan U, Sethuraman S. Electrospun Nanofibers as Scaffolds for Skin Tisssue Engineering.
Polymer Reviews 2014;54:348-376.

4. Velnar T, Bailey T, and Smrkolj V. The Wound Healing Process: an Overview of TheCelluler and Molecular Mechanisms. The Journal of International Medical Research. 2009;37:1528-1542.

5. Pavletic MM. Atlas of Small Animal Wound Management and Recontructive Surgery.3rd Ed. Iowa:Wiley-Blackwell; 2010.

6. Ramirez-Pliego O, Escobar-Zarate DL, Rivera-Martinez GM, Cervantes-Badillo MG, Esquivel-Guadarrama FR, RosasSalgado G, Rosenstien Y, and Santana MA. CD43 Signals Induce Type One Lineage Commitment of Human CD4+ T Cells. BMC-Immunology. 2007;8(30): 1-10.

7. Prabha M, Ramesh C, Kuppast I, and Mankani K. Studies on anti-inflammatory activities of Euphorbia tirucalli L. latex. Int. J. Chem. Sci. 2008;6(4):1781-1787.

8. Anief M. Ilmu Meracik Obat Teori dan Praktik. Yogyakarta: Gadjah Mada University Press; 2008

9. Qomariah, S. Efektivitas salep ekstrak batang patah tulang (Euphorbia tirucalli) pada penyembuhan luka sayat tikus putih (rattus norvegicus) (Skripsi). Semarang: Universitas Negeri Semarang; 2014.

10. Aisah S. Efektivitas salep ekstrak batang patah tulang (Euphorbia tirucalli) pada penyembuhan luka bakar tikus putih (Rattus norvegicus) (Skripsi). Purwokerto:Universitas Muhammadiyah Purwokerto; 2016

11. Carpenter J, Mashima Y, Rupiper D. 2001. Exotic Animal Formulary 4th edition. Missouri: Elsevier Saunders; 2012.

12. Bush JA, Ferguson M, Mason T, and McGrouther DA. Skin Tension or Skin Compression? Small Circular Wounds are Likely to Shrink, Not Gape. JPRAS, 2008;61: 529-534.

13. Takeo M, Lee W, Ito M. Wound Healing and Skin Rgeneration. Cold Spring Harb Perspect Med. 2015;5:1-12

14. Kutsukake M, Shibao H, Uematsu K, Fukatsu T. Scab formation and wound healing of plant tissue by soldier aphid. 
Proceeding of The Royal Society. 2016; B276: 1555-1563.

15. Bhagyashri C, Jogendra $H$, Avinash P. Plant Latex: An Inherent Spring of Pharmaceuticals. World Journal of Pharmacy and Pharmaceutical Science. 2015;4(4): 1781-1796.

16. Lin M, Lin A, Wu D, Wang S, Chang F, Wu Y, Huang Y. Euphol from Euphorbia tirucalli selectively inhibits human gastric cancer cell growth through the induction of ERK1/2-mediated apoptosis. Food and Chemical Toxicology. 2012;50: 4333 4339.

17. Landen N, Li D, Stahle M. Transition from inflamation to proliferation: a critical step during wound healing. Cell. Mol. Life Sci. 2016;73: 3861-3885.

18. Pastar I, Stojadinovic D, Yin N, Ramirez H, Nusbaum A, Sawaya A, Patel S, Khalid L, Isseroff R, Tomic-Canic M. Epithelialization in Wound Healing: A Comprehensive Review. Advanced in Wound Care. 2014;3(7):445-464

19. Bainbridge P. Wound Healing and The Role of Fibroblast. J Wound Care. 2013;22(8):407-412
20. Tracy L, Minasian R, Caterson E. Extacellular Matrix and Dermal Fibroblast Function in the Healing Wound. Advances in Wound Care. 2014;5(3): 119-136.

21. Li B dan Wang J. Fibroblasts and Myofibroblasts in Wound Healing: Force Generation and Measurement. J Tissue Viability. 2011;20(4):108-120

22. Havran $\mathrm{W}$ and Jameson J. Epidermal $T$ cells and wound healing. J. Immunol. 2010;184(10): 5423-5428.

23. Chen L, Mehta N, Zhao Y, DiPietro L. Absence of CD4 or CD8 Lymphocytes Changes Infiltration of Inflammatory Cells and Profiles of Cytokines Expression in Skin Wounds, but does not impair healing. Exp. Dermatol. 2014;23(3):189194

24. Avelar B, Lelis F, Avelar R, Weber M, Souza-Fagundes E, Lopes M, MartinsFilho O, Brito-Molo G. The crude latex of Euphorbia tirucalli modulates the cytokine response of leucocytes, especially CD4 $4^{+}$lymphocytes. Rev. Bras. Farmacogn. 2011;21(4): 662-667 